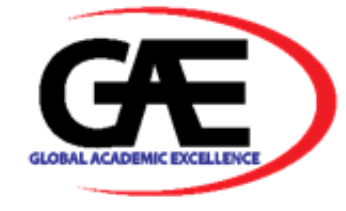

www.ijlgc.com

\title{
THE UNEQUAL CONTRACT OF NUCLEUS-PLASMA REGARDING PALM OIL IN CENTRAL SULAWESI
}

\author{
Agus Lanini ${ }^{*}$, Fatimah Maddusila ${ }^{2}$, Sulbadana $^{3}$, Lembang Palipadang $^{4}$ \\ 1 Universitas Tadulako, Indonesia \\ Email: aguslanini@gmail.com \\ 2 Universitas Tadulako, Indonesia \\ Email: maddusila@gmail.com \\ 3 Universitas Tadulako, Indonesia \\ Email: sul_45@yahoo.co \\ $4 \quad$ Universitas Tadulako, Indonesia \\ Email: lembang@gmail.com \\ * Corresponding Author
}

\section{Article Info:}

\section{Article history:}

Received date: 01.08 .2020

Revised date: 15.08 .2020

Accepted date: 10.01 .2021

Published date: 05.03.2021

\section{To cite this document:}

Lanini, A., Maddusila, F., Sulbadana \& Palipadang, L. (2021). The Unequal Contract of Nucleus-Plasma Regarding Palm Oil in Central Sulawesi. International Journal of Law, Government and Communication, 6 (22), 74-84.

DOI: $10.35631 /$ IJLGC.622007.

This work is licensed under CC BY 4.0

\begin{abstract}
:
Contract of nucleus-plasma is an affirmative regulation over any company applied concession for agriculture. Every Palm plantation company that holds concession over 100 hectares is required to apply a nucleus-plasma contract. The problem has arisen since the contract arranged and dominated by the company during the contract period. Research aims are to investigate the contract in an equal position for both parties, to explain legal implications faced by the parties in implementing the contract, and to describe the palm oil agribusiness development prospect through the nucleus-plasma contract. Legal research method and such approaches as statutes, content, and comparative. These would be done by library and field researches. The research location is in Lalundu and Bungku. The research revealed; first, the parties palm farmer (plasma) and Plantation firms (nucleus) are unbalanced positions in the contract which its dominated by the firm in a construct of contract clausal., secondly, by the contract will occur such impact as convert land right (levering), breach of contract., Finally, Palm agribusiness development will support economic development in Central Sulawesi.
\end{abstract}

Keywords:

Un-Equal; Contract; Nucleus; Plasma; Palm Oil 


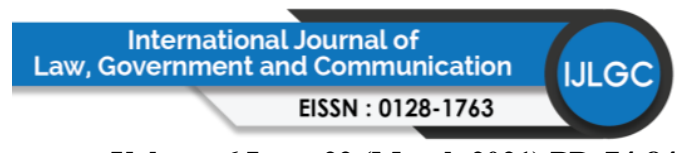

Volume 6 Issue 22 (March 2021) PP. 74-84

DOI 10.35631/IJLGC.622007

\section{Introduction}

In Central Sulawesi province there are 55 private estates with a vast area of 422,427 hectares including palm oil plantations. Extensive palm oil plantations 713.217 hectares located in several regencies, such as the Donggala consist of seven plantations, Morowali five plantations, Luwuk five plantations, and Buol seven Plantations (Badan Pusat Statistik Provinsi Sulawesi Tengah, 2017, 2013).

PT Tamaco Graha Krida Witaponda, in Central and Western Bungku Morowali Regency. That company has hold site license since 1987 and 1989 and hold a license to use or cultivation rights (HGU) for 4.145 hectares. The company also has the widest palm plasma area about 6.000 hectares. While the PT Tani Lestari Teladan in Donggala Regency has about 6.891,42 hectares concession with the location status as cultivation rights (HGU).

Concerning the efforts of plantations have been set up in Presidential Instruction of Republic Indonesia Number 1 of 1986 concerning Guidelines for the Development of Palm Plantations with nucleus-plasma patterns (PIR-Pola Inti Rakyat). Mean all company plantation concession that subjects to the regulation have to use the scheme as the base on nucleus-plasma contract, where palm farmers and companies as parties.

There are two types of palm farmers involved in the scheme, whether regular palm farmers or transmigration palm farmers as parties of the contract because the government has also a transmigration program that related mentioned used to the contract named PIR-Transmigration. The program implementation through the development of the estate with the use of large concession as the nucleus that helps and guides the palm farmer's in the vicinity as a plasma in a system of mutually beneficial cooperation, intact, and continuous (INPRES RI PIR 1/1986, 1986; UURI Perkebunan 39/2014, 2014).

Plantation patterns nucleus-plasma may be referred to as a form of contract between palm farmers and palm plantation companies in the field of agro-industries palm oil. The contract performed based on the interests of both parties. The contract consists of the terms in the form of rights and obligations to be met by the parties. Its made/ arranged by the party that its economic position is stronger than palm farmers.

The palm oil agribusiness ventures had the palm farmers armed with limited knowledge, a helpless facing competition that demands mastery against the technology, capital, and information marketing. At the same time emerging companies in the fields of palm oil plantations such as PT. Lestari Tani Teladan and PT. Tamaco Graha Krida Witaponda in Central Sulawesi and some other companies have that advantaged. The previous research had found that company position can be categorized as a controlled subsystem agribusiness upstream (production and trade production tolls) and downstream (processing subsystem of agribusiness and trade results), Atriyani et all 2018, (Antriyani, Laapo, \& Lamusa, 2018)., Barret et all 2012 (Barrett et al., 2012), Bijman 2008 (Bijman, 2008), Euler et all 2017(Euler, Krishna, Schwarze, Siregar, \& Qaim, 2017), Wang et al.2014 (Wang, Wang, \& Delgado, 2014). Otsuka et all. 2016 (Otsuka, Nakano, \& Takahashi, 2016).

That is why the kind of business practices are not only detrimental to the party directly in such practices but is also detrimental to society in general. That sort of thing is considered disturbing public order, welfare, and general interest, however, there are many constraints faced such term 


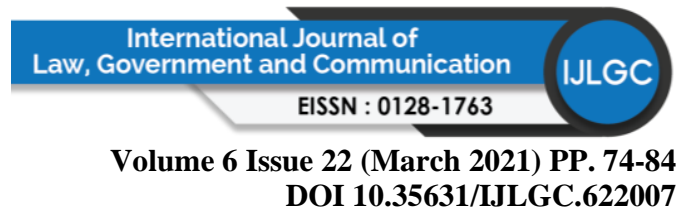

and condition of the contract tend to be dominated by the enterprise nevertheless, the form of the contract in general issued by the government (Baswir et al., 2009; Bellemare \& Novak, 2016; Euler et al., 2017).

What is the legal position of the parties in the contract, what are the legal implications facing the parties in the implementation of the contract and whether the contract can support the development of palm agribusiness in Central Sulawesi? These could be constructed by exploring and describing the contract and interviewing the parties as well as estimate the future development of palm oil plantations toward the economic development in central Sulawesi.

\section{Methodology}

This research was used the socio-legal type method, it tried to investigate and describe the content of contracts including the provisions that related and then compare to palm farmer respond of the contract exercised. The research also studied the degree of parties to obey the contract and how the contract influenced whether palm farmers or plantation companies complied with it (Biggs, 2017; Blandy, 2016).

Some observations and interviews to get a theoretical foundation in the form of expert opinions or information from the authorities in the level of province and regency as well as an expert from the university. Then interviewed freely both to the palm plantation companies on the level of management, chairman of villages cooperation unit (KUD) and several palm farmers. Respondents selected on purposive sampling were based on the level of accuracy (validity) sources of information, who are directly involved or related to the contract. Then data analyzed qualitatively.

Table 1. Profile Of The Selected Respondent Of The Research

\begin{tabular}{|c|c|c|c|c|}
\hline $\begin{array}{l}\text { The area/companies/ } \\
\text { Person Involved }\end{array}$ & $\begin{array}{l}\text { Palu city of } \\
\text { Province }\end{array}$ & $\begin{array}{l}\text { Regency of } \\
\text { Morowali }\end{array}$ & $\begin{array}{l}\text { regency } \\
\text { of } \\
\text { Donggala }\end{array}$ & Total \\
\hline $\begin{array}{l}\text { Provincial Transmigration and } \\
\text { Plantation Office }\end{array}$ & 3 & & & 3 \\
\hline District Plantation Office & & 3 & 3 & 6 \\
\hline Expert & 3 & & & 3 \\
\hline Manager & & $\mathbf{1}$ & $\mathbf{1}$ & 2 \\
\hline Chairman & & 1 & 1 & 2 \\
\hline Regular Palm Farmers & & 25 & 25 & 50 \\
\hline Transmigration Palm Farmers & & 25 & 25 & 50 \\
\hline Total of respondent & 6 & 55 & 55 & 116 \\
\hline
\end{tabular}

Source: Field Data

\section{Results and Discussion}

\section{The Legal Position of The Parties in the Nucleus-Plasma Contract}

The company's core as a private enterprise (BUMS), State-owned enterprises (BUMN) and the villages cooperation unit (KUD), they are doing business in the fields of plantations. Meanwhile, in the nucleus-plasma contract between farmers and PT. Lestari Tani Teladan and PT Tamaco, which acted as a party are the companies and the villages cooperation unit. Palm 


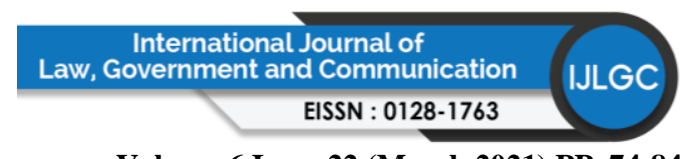

Volume 6 Issue 22 (March 2021) PP. 74-84

DOI 10.35631/IJLGC.622007

farmers position only as a participants land around the plantation companies and who have registered as a member of the cooperation unit village (KUD).

There is three cooperation villages unit (KUD) located around the plantation companies. In signing the contract, the farmers are represented by the chairman of the villages unit cooperation with a grant letter of power. This position is taken into account following article 1792 in conjunction with 1793 Indonesia Civil Code/ KUHPerdata. But the chairman as party acting for and on behalf of the palm farmers is limited (KUHPerdata, 1847).

The nucleus-plasma contract bore the legal relationship between the parties. Legal relationship as the relations that arise in the association named the village cooperation unit (KUD), which is governed by the law of course and consequence as the parties. This is done by determining the limits of the rights and obligations of the parties. Legal relationships that can occur between two or more parties. Parties entitled to accomplishment the lender is an active party obligated to meet the passive party as the debtor. The parties in an alliance called the mainstream subjects. I.e., the lender has the right and the debtor liable for achievement in performing. The debtor must always be known since it is important to insist on the fulfillment of the achievement. Achievements also were known by the term "performance" in the law of contract. it is intended as an implementation of the term and condition in the agreement (Otsuka et al., 2016; Patrick, 2004; Wang et al., 2014).

Based on the letter of obligation (debt letter) made between the palm farmers and the banks, it is a loan which legal relationship. The bank acts as the lender (lender) and the palm farmer as a borrower (the debtor). This is by clause article 1754 in conjunction with the 1765 Indonesia Civil Code. The question is where the cooperation position in the debt letter because in the contract of nucleus-plasma, chairman of the cooperation as represented of the palm farmers (KPTS MENTAN RI 353/2003, 2003; KUHPerdata, 1847; Rehber, 1998).

The cooperation acting for and on behalf of the palm farmers in the contract refer to the annexes of the agreement the production and selling of the fresh fruit bunch (FFB). However, we could not found a cooperation position either in article 1754 or in annexes but in practical. The research found from the palm farmers, as the results of the interview, stated that the obligation of cooperation in the contract as follows:

1. Collecting the results of farmers and channel it to the company's core.

2. Provides purpose members (smallholders) among other facilities and production, nine necessities and serve save borrowed.

3. Being a guarantor of farmers to get credit banking outside Bank of Executor.

4. Cutting plasma farmer's credit installment.

5. As a stabilizer and dynamizator between the core company and the farmer.

The legal relationship between the companies and palm farmers is giving of power under article 1792 Indonesia Civil Code. Therefore, the chairman of the cooperation, acting for and on behalf of the farmers, who represent each of the rights and obligations of the plasma farmers, in the production and selling the results of fresh fruits bunch (FFB). Because palm farmers ware delegated to the cooperation, so it has power as represents to manage and administer the interests of the palm farmers. 


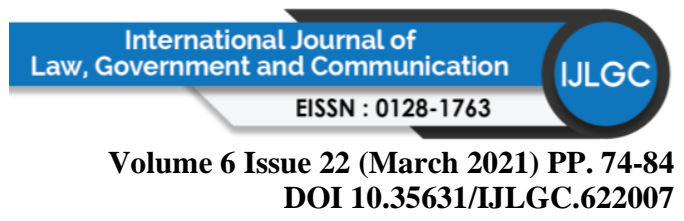

The strength of the bargaining positions of the (bargaining power) unbalanced occurs if the parties can enforce the will of the powerful but quite weak, so the weak parties follow only the terms of the contract. Other terms are used these powers to impose the will of, so bring an advantage to him. An inefficient provision of the contract in the production and selling of fresh fruit bunches (FFB) from the company's core and plasma farmers, among others, contained in article 2 of the contract, which stated:

"The first party that carried out maintenance of drainage channels, the road of the vineyards to launch the course of water and maintain the road condition from all-weather disturbance to prevent disruption of the activities of the harvest. The costs required for the activity in question will be borne in prorated by the palm farmers of the participants based on costs agreed by both parties that count from the receipt of the proceeds of large fresh fruit bunches (FFB)".

The company imposes unnecessary costs on oil palm farmers because the company controls a wider area of land as well as production transportation equipment that uses only the company's roads. So that maintenance costs do not need to be borne by farmers because these costs are the responsibility of the company. Because it is not fair if oil palm farmers participate in financing the needs of maintaining company facilities from the sale of farmers' production, and even then at the price set by the company.

Article 3 of the contract, stated, "Both parties stated that all maintenance activities and harvesting will be done in a group formed by the participants themselves". Pay attention to the content of article 2 of the contract above, very cornered position of farmers, with the presence of the word expressed approval that, "all maintenance activities and harvesting will be done in a group formed by farmers themselves". Article 2 of that agreement is contrary to article 1321 Indonesia Civil Code which stated, "not a valid if agreed it was given because of the careless or acquired due to coercion or fraud".

The legal position of the parties in the contract seems dominated by the companies even it is base on a government form. The dominant parties have settled the contract that associated with their profit-oriented as a company without considering the farmer interest that hangs their life on the harvesting from their palm oil. Nevertheless, the cooperation as a representative of the farmer in taking account incapability to comprehend the principles and purposes of the contract. The consequence of the condition created weak position for the palm farmer because of less knowledge to be a parties more ever, it is very dangerous if the referent commit a mistake by making conspiration with the company (Bellemare \& Novak, 2016; Frida, 1997; Gatto, Wolni, Asnawi, \& Qaim, 2017).

The parties in the agreement should be clear so that qualified legitimately an agreement as provided for in article 1320 Indonesia Civil Code. Palm 1 farmers as parties in the general interest to sell his crop were palm oil plantation company party is the party that buys the crops farmers. In the nucleus-plasma contract attached to a clause concerning capital where palm farmers in carrying out its business require capital support is not a little. Farm business capital in the sense of micro, factors of production capital is provided, processed and controlled in a palm farmer, good company agroindustry, as well as a still-modest farmer. 


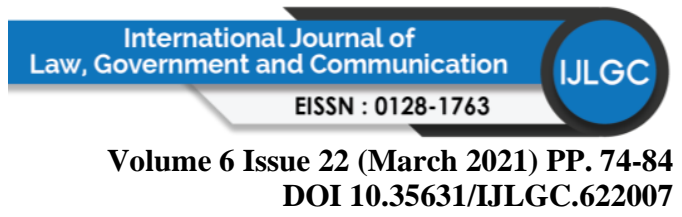

\section{Legal Implications for the Parties in the Nucleus-Plasma Contract}

Production agreements and sale and purchase fresh fruit bunches (FFB), hereinafter referred to as FFB created by the companies. The contract between palm farmers and PT. Tamaco, are a standard contract. The agreement, made by parties which company setting up the standard requirements in the form of an agreement that had already been printed and then submitted to the palm farmers to be approved, with almost the same freedom does not give once to the palm farmers for negotiating on the terms that they had made (Frida, 1997).

Book III Indonesia Civil Code revealed "freedom of contracts" in terms of the contract (benginsel der contractsvijjheid). The principle of freedom of contracts is an implementation of article 1338 Indonesia Civil Code which states: "Any agreement made legally, valid as legislation for those who create it" (Hasan, 1996; Little \& Watts, 1994; Sulistyarini, Budiono, Winarno, \& Koeswahyono, 2018). Actually, referred to the article, unless other that the contract "binding" of both parties. Thus the article guaranty for the parties to arrange what kind their contract types and its substance unless contradiction to the article 1320 Indonesia Civil Code (KUHPerdata, 1847).

Article 1320 paragraph (4) in conjunction with article 1337 Indonesia Civil Code determines that the parties should not make agreements regarding causa prohibited by law or contrary to morality or contrary to public order. The agreement created for the causa prohibited by legislation, are contrary to morality or contrary to public order is not valid (KUHPerdata, 1847). So far, in the contract between the palm farmers and PT. Tamaco, where PT. Tamaco in Palm oil plantations was setting the content of the contact not merely left to the parties but will need to be overseen by the government as the last of the public interest (public service) that maintain the balance of the interests of the individual and the interests of the community. The agreement in which there is a violation of the legislation and public order, the government can ban the contract were made, however, the role of government is only in the text but almost omission (Glover \& Kusterer, 1990).

According to article 5 of the contract refer to the annexes of the production and selling of fresh fruit bunches (FFB), Palm farmers and the company stated, "the second party is obligated to sell all FFB to the first party to be processed and marketed. The first party is obligated to buy fresh fruit bunches /TBS submitted the second party with the prices following the provisions of the Government". When these provisions are violated then they qualified as a tort action. Tort in the nucleus-plasma contract between the company and palm farmers can occur either from the company or palm farmers. Company party tort may occur if the company paid the late results processing palm farmer fresh fruit bunches, then the palm farmers can apply for interest from the money paid late. the magnitude of the delay interest shall be negotiated between the farmers and the companies (Barrett et al., 2012; Colchester, Sawit Watch (Organization), \& Forest Peoples Programme, 2006; Gatto et al., 2017; Glover \& Kusterer, 1990).

Instead of the company's core set of regulations related to the delay of the palm farmers send bunches of fresh fruit to the company over its production. The provisions mentioned in order the palm farmers late depositing his crop to the company, then the delay imposed upon the cut price of $2 \%$ from the cost of goods per day of delay. The longest delay of three days from harvest (Antriyani et al., 2018; Frida, 1997). 


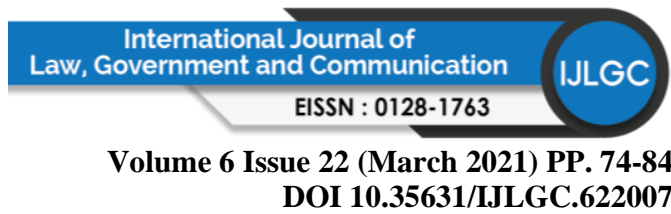

The farmers could not fulfill for all obligation that has been agreed by the representing because they felt it is very hard to perform what contract command due to unequal position in their rights and obligation. The palm farmers said how could to sell fresh fruits with low prices to the company while the other company paid more.

Based on the observations and investigation, can be designed a solution agreement is expected to give the legal position of the parties in a balanced way according to or based on the achievements of each party as well as a result of the contract that can ensure legal certainty of the parties.

The nucleus-plasma contract in the form of a common includes several types of contracts which are generally carried out based on chapter II of the Book III Indonesia Civil Code especially concerning the purchase agreement and the credit agreement. This agreement is generally done between the farmers and company as a direct agreement between two parties even though in this research focused on the nucleus-plasma contract (Glover \& Kusterer, 1990; Guo, Jolly, \& Zhu, 2007; Kadarsan, 1998; Key \& Runsten, 1999).

The Nucleus-Plasma Contract and the Development of Agribusiness in Central Sulawesi The dynamics of the interaction between the companies party and palm farmers in relationships, not sterile from the influenced of policy and government intervention. It can be included as one of the decisive key successes and failures or other results of the nucleus-plasma contract.

Government policy encourages both palm farmers including transmigration palm farmers and palm oil plantation companies taking account in developing the plantation. Granting such a license as well as land for palm farmers during the time enhanced by the government.

In general terms, the rights and obligations of the company's and palm farmers engaged in a pattern of nucleus-plasma (PIR-BUN) in the province of Central Sulawesi, is set in the Local Regulation Number 7 of 1994 concerning Coaching and Development Pattern of PIR-BUN in Central Sulawesi province (PERDA ST PIR BUN 7/1994, 1994).

The development of palm oil plantation is a significant increase it is showed from companies license issued in Central Sulawesi grew 36 of which already hold the plantation business permit (IUP) and 18 in the form of a site license. The company's location status as much as 15 units have held the cultivation rights (PP RI HGU HGB HP 40/1996, 1996) and generally of they have to make the nucleus-plasma contract.

Despite the palm plantation above, some related companies have been operated in central Sulawesi. Such a company was PT Hardaya Plantation operated in the Regency of Buol where holds an area of 16,709 hectares. There are about 12,509 hectares as cultivation rights and 4,200 hectares as the plasm (farmers) owned (Ministry of Agriculture, 2017).

The next largest companies, namely PT Mulyadi. The area concession in Luwuk Banggai Regency where have of 16,009 hectares. The area as much as 10,927 hectares of which status of plasma or farmers owned, while the company is about 5,082 hectares as cultivation rights. These figures explained the development of agribusiness in central Sulawesi in promoting the 


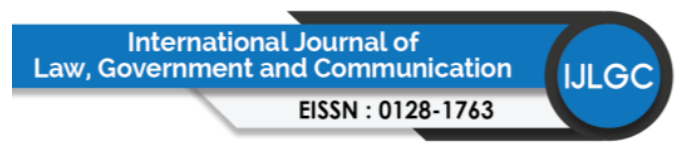

Volume 6 Issue 22 (March 2021) PP. 74-84

DOI 10.35631/IJLGC.622007

economic growth in the region (Badan Pusat Statistik Provinsi Sulawesi Tengah, 2013, 2017; Ministry of Agriculture, 2017).

The number of palm plantations mostly area in Morowali Regency for the amount of 1.82 million trees, followed by Donggala 0.90 million trees. Their total area cultivated about 189,539 hectares and produce around 413,559 tons of palm oil (Ministry of Agriculture, 2017). However, private estate gain more benefits because all palm farmers are not allowed to sell their products outside of the company according to the contract signed.

Base on the problems and to encourage the development of palm oil in the area of central Sulawesi, which all parties in the nucleus-plasm contract have to be required proportionately that can give opportunities to palm farmers to develop oil palm ventures at once increased their welfare. It can be seen from the great numbers of palm farmers to expand acreage over palm oil groves because the price of palm oil is an increasingly growing day. In general through the nucleus-plasma contract between palm farmers and palm oil plantation company can support the increased development in Central Sulawesi, as seen from the absorption and/or oil palm farmers involvement both local farmers as well as transmigration, taxes from companies that received by local governments, and other economic benefits that accrue to the communities (Antriyani et al., 2018; Baswir et al., 2009; Colchester et al., 2006; Euler et al., 2017).

However, the classic problem occurred where the needs of palm farmers in the economic field, government economic policies, and the influence of the global economy have caused palm farmers to experience some difficulties and even losses due to the instability of oil prices. According to palm farmers, the operational costs of maintaining palm 1 are greater than the selling price of fresh palm fruit bunches (Interviwed, 2019). However, private companies continue to experience significant growth because they have some comparative advantages, especially technology that can produce diversified oil products other than oil.

Really, what is the palm farmers problem has been tried to solve through government financial programme. such a credit program offered by bank state-owned where expected palm farmers from all layers can participate. Government financial program had two types of credit such as good credit is a type of assistance, as well as credit for the weak economy with all the facilities that hope relieve the palm farmers from finance problems (Barrett et al., 2012; Colchester et al., 2006; Euler et al., 2017; Glover \& Kusterer, 1990).

Granting credit is one of the types of businesses the bank, by the funds, gathered from the public and redistributes to the people who need help funding. Channeling credit is government assistance programs (in the form of a credit program of Bank Indonesia) among others in the form of business farmer credit (KUT). However, all the of the financial programme faced some constraints prominently palm farmers are still bound of the nucleus-plasm contract that has been agreed by the parties. This means many obligations of the palm farmers caution to unable to arrange a new contract, especially financial contract.

However, the data shows the growing business of oil palm plantations is increasing both in terms of the number of company licenses and the realization of the investment. Although it is not comparable with the efforts of smallholder oil palm plantations, oil palm farmers as plasma also experience growth so that they encourage an increase in the ability of oil palm farmers to meet their needs and can even set aside part of their income as savings. 


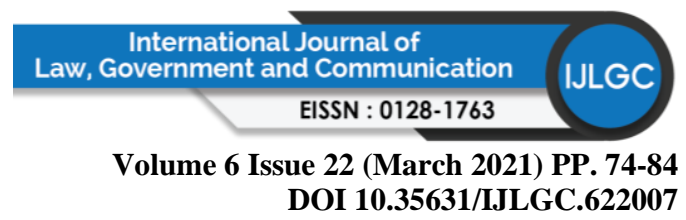

Indeed, in terms of equitable development results in the field of oil palm plantations have not been able to contribute adequately, but the derivative effects of an investment in oil palm plantations are felt by the surrounding community, including smallholders and their families. Similarly, the absorption of labor by companies both laborers in plantations and palm oil processing factories. Even the loading and unloading workers and palm oil transportation equipment rental during the harvest season felt an increase in income/income from the oil palm plantation company.

The contribution of oil palm plantations to tax revenues, especially the crude palm oil tax, will be a potential state revenue because palm oil production will increase every year. This is following the increasing number of oil palm plantations whether companies or private farmers owned.

In line with this description, the prospects for the growth or development of the palm oil industry in Central Sulawesi can be said to be still bright. Because this area is still relatively new in the development of oil palm plantations compared to the islands of Sumatra and Kalimantan, even most of the concession areas of oil palm companies have not yet been planted so that in the next few years the land will be managed and produced. Thus it can be said that Central Sulawesi has the opportunity to be developed through oil palm agribusiness.

\section{Conclusion(s)}

The legal position of the parties in the contract of the core plasm that the company palm oil plantations of PT. Tamaco and PT. Lestari Tani Teladan can be said as unequal in the determination of his rights and obligations. The companies tend to be more dominate the determination of the content of the clause of the agreement compared to oil palm farmers.

The legal implications faced by the parties are severe constraint after signed the agreement such achievement in performing as low price of crop, too long for farmers to pay their debt, and others sanction for farmers for delaying to perform the contract even may include either party's tort, the transition of land rights, and cancellation of the agreement.

The development of palm oil agribusiness supports economic development in Central Sulawesi in order for the involvement of oil palm farmers as part of the development goals in the form of an increase in the well-being of farmers in Central Sulawesi.

\section{Acknowledgments}

We wish to address our appreciation and thanks to the Directorate of Higher Education of Republic Indonesia for supporting the research and Universitas Tadulako for facilitating the research.

\section{References}

Antriyani, N., Laapo, A., \& Lamusa, A. (2018). Analisis Komoditi Basis Kelapa Sawit Pada Setiap Kecamatan Di Kabupaten Morowali. Agroland, 25(2), 136-144.

Badan Pusat Statistik Provinsi Sulawesi Tengah. (2013). Potret Usaha Pertanian Provinsi Sulawesi Tengah Menurut Subsektor. Palu: Badan Pusat Statistik Provinsi Sulawesi Tengah. 


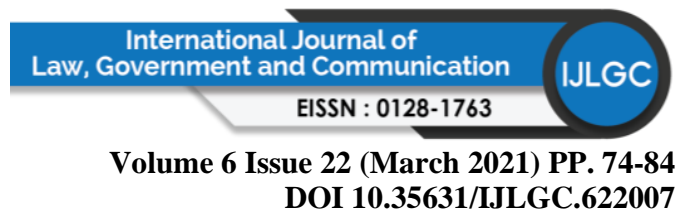

Badan Pusat Statistik Provinsi Sulawesi Tengah. (2017). Indikator Pertanian Provinsi Sulawesi Tengah 2017 (2017th ed.). Palu: Badan Pusat Statistik Provinsi Sulawesi Tengah.

Barrett, C. B., Bachke, M. E., Bellemare, M. F., Michelson, H. C., Narayanan, S., \& Walker, T. F. (2012). Smallholder Participation in Contract Farming: Comparative Evidence from Five Countries. World Development, 40(4), 715-730. https://doi.org/10.1016/j.worlddev.2011.09.006

Baswir, D. R., Achmad, N., Si, S., Si, M., Santosa, A., Indroyono, D. P., ... Ip, S. (2009). Pekebun Mandiri Dalam Industri Perkebunan Sawit Di Indonesia. Yogyakarta: PUSPITEK-UGM-SAWIT WACHT.

Bellemare, M. F., \& Novak, L. (2016). Contract Farming and Food Security. American Journal of Agricultural Economics, aaw053. https://doi.org/ 10.1093/ajae/aaw053.

Biggs, M. (2017). Sociological theory, theoretical perspective. Retrieved from ox.ac.uk/ sfos0060/Perspectives5.

Bijman, J. (2008). Contract Farming in Developing Countries: An overview. Retrieved from Wageningen University, Department of Business Administration website: http://edepot.wur.nl/1763

Blandy, S. (2016). Socio-legal approaches to property law research. In S. Bright \& S. Blandy (Eds.), Researching Property Law (pp. 24-42). https://doi.org/10.1007/978-1-13748618-9_3

Colchester, M., Sawit Watch (Organization), \& Forest Peoples Programme (Eds.). (2006). Promised land: Palm oil and land acquisition in Indonesia: implications for local communities and indigenous peoples. Bogor, West Java, Indonesia: Moreton-in-Marsh, England: Perkumpulan Sawit Watch; Forest Peoples Programme.

Euler, M., Krishna, V., Schwarze, S., Siregar, H., \& Qaim, M. (2017). Oil Palm Adoption, Household Welfare, and Nutrition Among Smallholder Farmers in Indonesia. World Development, 93, 219-235. https://doi.org/10 .1016/j.worlddev.2016.12.019

Frida, R. (1997). Get to Know the Farm Contract. Bandung: AKATIGA.

Gatto, M., Wolni, M., Asnawi, R., \& Qaim, M. (2017). Oil Palm Boom, Contract Farming, and Rural Economic Development: Village-Level Evidence from Indonesia. World Development, xx, xxx-XXXX. https://doi.org/10.1016/j. worlddev. 2017.02.013

Glover, D., \& Kusterer, K. (1990). Small Farmers, Big Business. https://doi.org/10.1007/9781-349-11533-4

Guo, H., Jolly, R. W., \& Zhu, J. (2007). Contract Farming in China: Perspectives of Farm Households and Agribusiness Firms. Comparative Economic Studies, 49(2), 285-312. https://doi.org/10.1057/palgrave.ces.8100202

Hasan, D. (1996). Lembaga Jaminan Kebendaan Bagi Tanah dan Benda Lain Yang Melekat Pada Tanah Dalam Konsepsi Penerapan Asas Pemisahan Horizontal. Bandung: Citra Aditya Bhakti.

INPRES RI PIR 1/1986. Instruksi Presiden Republik Indonesia Nomor 1 Tahun 1986 Tentang Pengembangan Perkebunan Dengan Pola Perusahaan Inti Rakyat. , INPRESRI 1/1986 $\S(1986)$.

Kadarsan, H. w. (1998). Agricultural Finance and financing firms. Jakarta: Rajawali Press.

Key, N., \& Runsten, D. (1999). Contract Farming, Smallholders, and Rural Development in Latin America: The Organization of Agro-processing Firms and the Scale of Outgrower Production. World Development, 27(2), 381-401. https://doi.org/10.1016/S0305-750X(98)00144-2

KPTS MENTAN RI 353/2003. Keputusan Menteri Pertanian Nomor: 353/Kpts/Kb.510/6/2003 Tentang Perubahan Pertama Surat Keputusan Menteri Partanian Nomor 


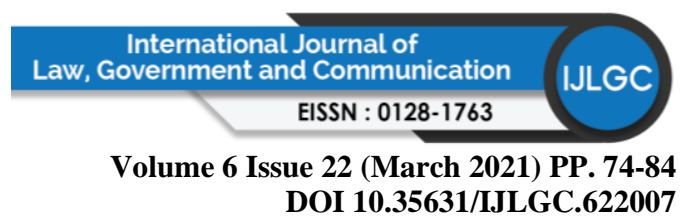

333/Kpts/Kb.510/6/1986 Tentang Tata Cara Pelaksanaan Pengembangan Perkebunan Dengan Pola PIR - Trans., Pub. L. No. 353/2003, 353/2003 4 (2003).

KUHPerdata. Indonesian Civil Code., Pub. L. No. April 391847 S.NO.23 (1847).

Little, P. D., \& Watts, M. (1994). Living Under Contract. Retrieved from https://books.google.com/books/about/Living_Under_Contract.html?id=uNPQrEdBXl $\mathrm{gC}$

Ministry of Agriculture. (2017). Statistik Perkebunan Indonesia 2015-2017/ Tree Crop Estate Statistics of Indonesia 2015-2017. Retrieved from http://ditjenbun.pertanian.go.id

Otsuka, K., Nakano, Y., \& Takahashi, K. (2016). Contract Farming in Developed and Developing Countries. Annual Review of Resource Economics, 8(1), 353-376. https://doi.org/10.1146/annurev-resource-100815-095459

Patrick, I. (2004). Contract farming in Indonesia: Smallholders and agribusiness working together; report. Canberra: Australian Center for International Agricultural Research.

PERDA ST PIR BUN 7/1994. Peraturan Daerah No. 7 tahun 1994 tentang Pembinaan dan Pengembangan Pola PIR-BUN di Provinsi Sulawesi Tengah. , Pub. L. No. PIR BUN 7/1994, PIR BUN 7/1994 (1994).

PP RI HGU HGB HP 40/1996. Peraturan Pemerintah Republik Indonesia Nomor 40 Tahun 1996 Tentang Hak Guna Usaha, Hak Guna Bangunan Dan Hak Pakai Atas Tanah Presiden. , Pub. L. No. 40/1996, 40/1996 (1996).

Rehber, E. (1998). Vertical Integration in Agriculture and Contract Farming. Working Paper, Bursa.

Sulistyarini, R., Budiono, Abd. R., Winarno, B., \& Koeswahyono, I. (2018). The Benchmark of Freedom of Contract under Indonesian Treaty Law. Developing Country Studies, 8(2), 14.

UURI Perkebunan 39/2014. Undang-Undang Republik Indonesia Nomor 39 Tahun 2014 Tentang Perkebunan., Pub. L. No. 39/2014, 39/2014 (2014).

Wang, H. H., Wang, Y., \& Delgado, M. S. (2014). The Transition to Modern Agriculture: Contract Farming in Developing Economies. American Journal of Agricultural Economics, 96(5), 1257-1271. https://doi.org/ 10.1093/ajae/aau036 